\title{
ENGINEERING IN THE UNIVERSITY OF NOTTINGHAM
}

\author{
OPENING OF LABORATORY EXTENSIONS
}

$\mathrm{T}$ THE original engineering laboratories of University College, Nottingham, as it then was, were completed in 1930, and until 1948, apart from a small extension of drawing-office accommodation, no further expansion was made. In 1930 the number of full-time students was 17 , a number which by 1940 had increased to 44 , and by 1946 (the date of the Barlow Report) to 128 . In 1950 there were approximately two hundred students reading for degrees in engineering; this number was really far in excess of the facilities at the University's disposal, and adequate training was only given by running dual streams of undergraduates in each year. Such conditions could only be tolerated for a short time to meet a national emergency, and a further demand on accommodation was made when, on the University receiving its charter in 1948 , it became possible to develop further the research schools in applied science.

The University was faced with the preparation of a long-term scheme for the development of technology, or of putting into operation a smaller scheme which would bring relief with the shortest possible delay. The first scheme would certainly have taken six years to plan and complete, and in this time the intake of applied science students would have had to be reduced. This seemed contrary to the national interest, and so it was decided to proceed with the smaller project which could be completed in a little more than two years, during which time the student numbers could be maintained and active research schools developed. The project has now been completed, the immediate extra accommodation provided by the extensions representing an increase of some 60 per cent; when rooms at present loaned to the Arts Faculty are available, the total increase of accommodation will be 80 per cent, making possible an intake of students at the rate of ninety a year.

The extensions to the laboratories were opened on April 14 by Lord Hives, chairman and joint managing director of Rolls Royce, Ltd. Lord Hives pointed out that, although society to-day is increasingly dependent on the achievements of applied science, too few of the present-day university students in Britain study this vital subject-only a sixth, in fact, of the 72.5 per cent at universities who are in some measure or other assisted financially by the State. That the percentage of technological students is so small is causing both educationists and industrialists much anxiety, and Lord Hives noted with satisfaction that Nottingham anticipated some time ago the increase in the facilities required for training.

In Lord Hives's opinion, the reason for the unsatisfactory state of recruitment is not to be found at the level of the university, but is something much deeper : it is to be found in the schools and in the attitude of mind of a great number of the parents in Britain. Since engineering, even in its fundamentals, is not taught in schools, too often when a boy comes to consider what he should study at the university, or what career to take up straight from school, he knows nothing at first hand of one of his country's greatest possible careers-engineering.

A distinguished careers master, Mr. Howard Ruby, of Dulwich College, put the position very neatly when he wrote recently that even when careers masters are well aware of the good prospects in an industrial career, their problem is to convince parents and boys, for there still survives in the minds of some parents the view that a career in industry is not so respectable as one in the Armed or Civil Services or other professions. Such a point of view is not only out of date but also harmful, and so long as it persists Britain will never have the skilled men that it requires. A unique place in the estimation of the world has been earned for Britain by its craftsmanship, the skill of its engineers and technicians and the ingenuity of its scientists, and it is necessary that young men should come forward in increasing quality and numbers for past triumphs to be maintained and even exceeded. The main lesson to be learnt from the United States is the high position in society given to industry in that country. As one of the recent Anglo-American productivity teams said in its report: "It is because of this social and intellectual prestige attaching to the highest. position in industry that many of the best students choose industry for a career". Lord Hives emphasized the fact that in the engineering industry many of the key positions at the very top of the tree are held by trained engineers. In fact, there is no better training for an executive in the industry to-day than to have worked in his time as a skilled engineer. Yet to many people engineering is still something 'messy', something that polite young men ought not to get mixed up in. Technical engineering, on the other hand, can be the most exciting and fascinating way of earning a living, and the chief reason for this is that it can never remain static.

Prof. J. A. Pope, head of the Department of Civil and Mechanical Engineering in Nottingham, thanked the University Grants Committee and members of industry who through their generous support had made the developments possible, and paid tribute to the University surveyor, Mr. J. W. Popplewell, and his staff on achieving a useful and economical design of building; the capital expenditure per student place had been kept very low without any sacrifice of student amenities or teaching efficiency.

\section{BRITISH GELATINE AND GLUE RESEARCH ASSOCIATION \\ RESIDENTIAL CONFERENCE}

$\mathrm{T}$ HE first residential conference of the British Gelatine and Glue Research Association was held at Hulme Hall, University of Manchester, during April 8-11, and the progress made in the first two and a half years of research work was reported. The meeting was well attended, those present including representatives of gelatine and glue manufacturing firms, of firms using these products, and of government laboratories, research associations and university departments.

The Conference Lecture, by Dr. G. R. Tristram (University of St. Andrews), reviewed recent progress 